\title{
Stereotomy: Stone Architecture and New Research by Giuseppe Fallacara
}

\author{
Peter Attila Andrusko
}

Published online: 27 June 2014

(C) Kim Williams Books, Turin 2014

From the point of view of this reviewer, it would be difficult to tailor a more appropriate book for the Nexus Journal to review than Stereotomy: Stone Architecture and New Research, a newly published work by Prof. Giuseppe Fallacara.

To quote Joël Sakarovitch: "Stereotomy can be studied from the standpoint of its relationship to the history of architecture, the applied geometry used by the stone cutter, the erudite geometry of the mathematician, studies in the field of mechanics, and the history of crafts and their emergence."

The practice of stereotomy is quite literally the origin point at which mathematics begins to describe the physical dimensions of the individual building blocks of an architectural composition. Stereotomy is by definition architecture described mathematically.

Likely common to most readers, my first introduction to the term "Stereotomy" was sourced from the album title of an English musical group popular in the 1980s, which I discovered only later was in reference to an Edgar Allen Poe verse describing a stone architectural element; so, when a stone-carver colleague of mine in 2005 showed me his newly acquired rare book on 19th century English stone cutting entitled "Stereotomy", it immediately drew my attention, which was rapidly followed by a quick, short burst of covetous desire for the long lost treasures I discovered bound between its tattered covers. As I pored through the riot of equations and amazingly complex drawings I recall feeling a surge of awe at the mere existence of such codified knowledge and engineering know-how from a somewhat mysterious time so far in the past.

For those readers unfamiliar with the term "stereotomy", a rudimentary definition would be: the art and science of cutting three-dimensional solids into

P. A. Andrusko $(\square)$

The Andrusko Group, 6424 SE 122nd Avenue, Portland, OR 97236, USA

e-mail: peter@andruskogroup.com 
particular shapes. The English term is derived from the French, "stéréotomie," which sources from the Greek: $\Sigma \tau \varepsilon \rho \varepsilon o ́ \varsigma$ "solid" and To $\mu \eta$ "cut."

While the specific term was documented for the first time in the late 17th century (perhaps, not coincidentally, soon after the important mathematical contributions of René Descartes), it wasn't until the mid- to late 19th century that the earliest, more well-known academic manuals were published, principally for civil engineering applications related to rail road construction, with the objective of maximizing the static loads and structural utility of the traditional stone building materials that were required to support the colossal and movable mass of material that was for the first time possible with steam engines and rail.

Traditionally the exclusive domain of the builder-architect and operational master masons, the art and science of stereotomy was a natural progression and culmination of the rich and strictly stratified mechanism of production specializations from the sourcing of materials in the quarry to the setting of finished stones in the most magnificently designed of our rich body of architectural achievements.

This highly-evolved technical and aesthetic know-how appears to haveironically-reached its apex just as new materials and building technologies exploded onto the architectural scene-also beginning in the mid- to late 19th century-and it quickly lost its short, but revered, place in the building arts to the new building methodologies based primarily on structural steel construction and was only further diminished through the development of our modern aesthetic architectural canon which has all but eliminated traditional stonework and any form of ornamentation from the vocabulary in modern structures.

This natural evolution has also resulted in the separation of the traditional building disciplines described by Sakarovitch from its common roots in stone building construction into our modern, distinct and almost unrecognizably different disciplines of stone quarrying, stone-processing, engineering, architecture and decorative arts design.

There was a time-and not so very long ago-when the master builder was knowledgeable and intimate with his local materials, was designer, architect, engineer and ornamentalist, and was a close friend and colleague to the master mason and stone carver. This new construction paradigm has replaced millennia of tradition and often appears to deliberately eschew any use of stone-certainly as a core structural material-if not, an outright elimination of anything overtly classicist or ornamental.

Much of the past 125 years of architectural design and construction seems to this stone carver to be more a celebration, exploration and exploitation of new materials and building technologies than concerned with human aesthetic sensibilities and traditional forms; certainly, this seems to be more the case in US architectural design practice as there is no vast, extant, historical precedent and no cultural imperative, as is the case in most of Europe; interestingly it appears to mirror the changes over time in modern and contemporary art.

René Descartes fundamentally changed his analogue world into our modern digital array. We see the beginnings of the import of his contributions in these early stereotomic works of the mid- to late 18th century, but the practical limits to designers really were the intense maths and staggeringly long hand calculations 
required to get anywhere interesting or useful. Effectively a very thick, tall and impenetrable wall to everyone but the most persistent, and even then only those most very basic achievements were within reach, until modern computational capabilities began with Turing's device and subsequent developments by the IBM card-reader team, ushering in the myriad realizable and now practical applications that the Cartesian space coordinates system offers.

Enter modern calculating machines, digitally controlled tooling and sophisticated 3D modeling software in the last decade, which again changes everything we think we know about architectural design, as these tools have also changed the nature of everything else around us.

This new work by Prof. Fallacara is an illuminating, modern chronicle of his research into the complex and beautifully mysterious practice of traditional architectural building methodologies using modern digital-based fabrication tools paired with sophisticated design and modeling software.

This work profiles an ambitious and robust number of his experimental building projects, as well as aspects of the why, and how, they are achieved using 3D design and modeling software coupled with new digital fabrication technology to recreate production methodologies of the past and to explore the realization of new designs that are only now becoming possible through the use of this technology.

The book encompasses three sections: a brief historical perspective of where stereotomy truly manifests in historic architecture; a presentation of progressively complex experiments and field test applications; and finally, projects and future projects.

Professor Fallacara takes us on a journey of exploration of our architectural past where few extant historical sources provide better demonstrable evidence of intellectual achievements by our precedents than those that exist in humanity's architectural record involving practical and magnificent works of stereotomy.

What we can see with our eyes and appreciate in our souls has rarely been exceeded and only then in art and music. The thousands of years of accumulative human effort spurs us on to greater heights of achievement as we use what is available to us in our time to push the properties of available materials and the technology at our disposal to find new, more efficient and aesthetically sublime ways to create a modern architecture we can call our own.

He next shows us that, with this technology, there are few if any limits for the computational abilities required to calculate loads; and how the materials can be pushed, resulting in the ethereal, magical lightness and splendor-an early goal of the master masons - which only foreshadowed the possibilities we now possess and only hinted at the potential now within the grasp of those imaginative souls at the forefront of entering this new and unexplored country.

Professor Fallacara seems to be asking whether these nearly forgotten traditional building techniques and construction forms have a legitimate place in the modern vocabulary of architecture, especially when considered through the prism of our modern computational abilities and the recent access to digital fabrication methodologies.

He rightly advocates for a restoration of what has always been the human connection to architecture: its aesthetic tapestry and ornamentation. The modern 
canon that eschews what we know in our souls to be a glorious past must make room and provide a rightful place to what can only be understood to create a synergistic harmony with those who inhabit our architecture. The creative palette has expanded exponentially with this technology and it is up to those who possess the aesthetic sensibilities and understand the technology to use these new tools to create a new architecture.

Through each of the examples in his book, he not only demonstrates the viability of this technology to efficiently reproduce the building blocks of past treasures, but proposes entirely new and practical means of surpassing the achievements of the past through the advancements in solid modeling software, robotic production tools and provides evidence of what could be.

The pragmatic formation of these shapes began with hand tools, originating from simple geometric methods established by our predecessors before recorded history; being the foundation stones and building blocks of our world's architectural heritage, we can trace the refinements and acquisition (and loss) of specialized building knowledge through the archeological remnants, and at many levels we are able to be awed by those of our predecessors who we know about that have demonstrated extraordinary intellectual and engineering achievement. In analyzing this record, we can see very clearly that during the past 125 years building and materials technology in architecture has experienced a very dramatic shift.

The message from Prof. Fallacara's new book demonstrates that an equally dramatic architectural shift is again upon us.

Peter Attila Andrusko's journey started as the eldest son of an European emigrant to the Western USA. His father learned the brick and stone masonry trade in 1960s middle-America: beginning as a hod carrier and elevating himself through his early apprenticeship and subsequent practical training to become a master of his craft. He is currently semi-retired and spends much of his time cultivating his vineyard and making wine. His eldest son managed to find his own way beginning his university study in the early 1980 s as an engineering major, ultimately earning an undergraduate degree in information systems and quantitative analysis. After a number of years of study and work in Europe, he returned to the US to begin a 25 years, self-directed career that has evolved from the most very basic of residential masonry construction to the building of an applied architectural arts studio which now utilizes a combination of traditional hand-craft tooling and digital fabrication technology to perform unique creative works for environmental graphics designers and architects in the built environment. He is actively pursuing sculptural and artistic interests using the digital fabricating technology that he has been assembling, modifying and adding to his studio production capabilities. 